\title{
DORMANCY AND GERMINATION OF ANNONA MACROPROPHYLLATA (ANNONACEAE): THE IMPORTANCE OF THE MICROPYLAR PLUG AND SEED POSITION IN THE FRUITS
}

\author{
Alma Rosa González-Esquinca', Iván De-la-Cruz-Chacón and luz María Domínguez-Gutú \\ Instituto de Ciencias Biológicas. Universidad de Ciencias y Artes de Chiapas. \\ ${ }^{1}$ Corresponding author: aesquinca@unicach.mx
}

\begin{abstract}
Annona macroprophyllata (papausa or ilama) is an economically important species of fruit that is consumed in large quantities in Central America and is considered to have the finest flavour of all of the custard apples (Annonaceae). This species presents propagation problems including the six-month dormancy of the seeds, which has not been fully explained. Among the factors affecting the germination of Annona seeds are the position inside of the fruit and the presence of a micropylar woody plug. The present work addresses the importance of these factors in the germination and dormancy of this species, using a randomised design with seeds from 169 fruits of the white variety of Annona macroprophyllata. The fruits were divided into three sections (basal, middle, and apical) in which seeds were evaluated for nine months with the following parameters: the size and weight of the seeds and the viability and germination percentage considering the presence or absence of the micropylar plug. The results show no correlation between the breaking of dormancy and either the position of the seeds in the fruit or the micropylar plug, but they do establish the importance of the micropylar plug for germination. The breaking of dormancy requires storage for the length of the dry season in the tropical deciduous forest, the habitat of these plants.
\end{abstract}

Key words: breaking seed dormancy, dormancy period, micropylar woody plug, population latency, seed position-dependent effects.

Resumen: Annona macroprophyllata conocida comúnmente como papausa o ilama es una especie frutícola de importancia económica, consumida en el sur de México y en América central; es considerada por su sabor, el fruto más fino de las anonáceas. Esta especie presenta problemas de propagación debido al periodo de latencia de hasta seis meses que tienen sus semillas, el cual no ha sido completamente explicado. Entre los factores que impactan la germinación de las semillas, están la posición de estas dentro del fruto y la presencia de un tapón micropilar leñoso. El presente trabajo investigó la importancia de estos factores relacionados a la germinación y latencia de esta especie. Para este estudio, se estructuró un diseño completamente al azar usando 169 frutos de Annona macroprophyllata de la variedad blanca. Los frutos fueron divididos en tres secciones transversalmente (basal, medio y apical), las semillas de cada sección fueron caracterizadas en tamaño y peso y por nueve meses fueron almacenadas y evaluadas con relación a su viabilidad y capacidad germinativa, considerando al mismo tiempo la presencia o ausencia del tapón micropilar. Los resultados no correlacionan la posición de las semillas en el fruto, ni el tapón micropilar con el rompimiento de la latencia, pero revelan la importancia del tapón micropilar para la germinación. El rompimiento de la latencia de esta especie depende del tiempo de almacenamiento, el cual está completamente asociado a la temporada de sequía de la selva baja caducifolia, donde esta especie habita.

Palabras claves: efecto de la posición de las semillas, latencia poblacional, periodo de latencia, rompimiento de la latencia, tapón micropilar leñoso.

$\mathbf{T}$ here are numerous studies of dormancy and germination, particularly regarding factors such as the hardness of the seeds and the anatomical or physiological maturity of the embryo. However, there are few studies that address the relationships between the periods of dormancy and germi- nation and the position of the seeds inside of the fruit or with the presence of a micropylar plug. It has been documented that in some species, the position of the seeds within the fruit is related to the mechanisms of dispersal, germination or dormancy (Baskin and Baskin, 2001; Moravcová et al., 
2005; Sharma et al., 2009; Hay et al., 2010; Wang et al., 2010; Graeber et al., 2013), demonstrating the ecological importance of this trait.

In some species, such as Xanthium pennsylvanicum, germination dormancy is restricted to the position of the seeds. As a survival strategy, this species can produce small seeds with dormancy and large seeds without dormancy in the same fruit, a type of dimorphism in germination (Esashi and Leopold, 1968). Additionally, a study of Eremopyrum distans showed that basal seeds of the spigot are larger and more numerous, with a higher proportion of dormant seeds, whereas the distal seeds are smaller and include a lower proportion of dormant seeds. This phenomenon is associated with the life history of the species (Wang et al., 2010).

Annona macroprophyllata Donn. Sm ( $\equiv$ Annona diversifolia Saff.) is a regionally important species of fruit that is distributed in Mexico, Guatemala, and El Salvador. Its seeds are difficult to propagate because of a dormancy that can be partially broken with $\mathrm{GA}_{3}$ (Campbell and Popenoe, 1968). The dormancy (6-7 months) has been attributed to various causes, including the immaturity of the embryo, the presence of a hard, waxy coating, or the lack of viability. However because the tissues are differentiated by the time the seeds are dispersed, it is clear that the problems with germination in this species are not related to the presence of rudimentary embryos nor because the hard and waxy cover represents a barrier to water intake and germination. Seeds with and without dormancy show viability greater than $90 \%$ (González-Esquinca et al., 1997); therefore, most of the seeds of this species contain a living embryo with the capacity to germinate. Another feature of this species is that neither seed storage time nor treatments with $\mathrm{GA}_{3}$ can completely break the dormancy. In fact, it is reported that collected seeds stored for one month and then treated with $\mathrm{GA}_{3}$ have only a $20.5 \%$ germination rate (Marroquín et al., 1997).

The factors that can affect the germination of these seeds include the seed position in the fruit and its relationship to the amount of reserves stored. For Annona species, it has been suggested that adaptations of the micropylar region, specifically the presence of a micropylar plug (Van Setten and Koek-Noorman, 1992; Svoma, 1998), may contribute to germination because the micropylar plug is woody and compact, potentially providing a physical barrier to the entrance of water. Thus, a parenchymal rupture could separate the micropylar plug from the mechanical cap of the mesotesta that surrounds it (van der Heijden and Bouman, 1988), allowing the emergence of the radicle. It is unknown whether the dormancy of A. macroprophyllata seeds could be related to the position of seeds in the fruit and/or to the presence of the micropylar plug. Therefore, the objective of this work was to evaluate the impact of both factors on germination and dormancy.

\section{Materials and methods}

Plant material. In September to October of 2011, 169 fruits of white Annona macroprophyllata were collected in the San Lucas region in the state of Chiapas, México. A reference specimen was deposited by the authors under voucher number 352 in the Eizi Matuda Herbarium (HEM) of the Universidad de Ciencias y Artes de Chiapas, UNICACH.

The fruits were divided into three homogeneous crosssections (groups) with respect to peduncle placement: basal (section attached to the stem), middle (central), and apical. The seeds from each section were separated from the fruit, washed with water and dried in the shade for one week. The seeds that appeared healthy were stored at room temperature in paper bags. One hundred seeds from each group were characterised with respect to mass (digital scales, Ohaus) length and Feret diameters (Vernier Truper, Mexico).

Viability assay. For this assay, 100 embryos from each group were assessed each month for nine months. Each set of embryos was added to $10 \mathrm{~mL}$ of $0.5 \%$ 2,3,5-triphenyl tetrazolium chloride (TTZ) and incubated in the dark for 2 $\mathrm{h}$ in a Biotronette ${ }^{\circledR}$ germination machine, at $28-30{ }^{\circ} \mathrm{C}$, with a relative humidity of $50-70 \%$; each assay was performed in triplicate. The number of stained embryos was reported as percentage of viability. The seeds were stored until use in brown paper bags and kept in boxes at room temperature.

Germination tests. Every month for nine months, the seeds of each group (basal, middle, and apical) were analysed and divided into two treatments, i.e., seeds with a micropylar plug and seeds without a micropylar plug, using a completely randomised $3 \times 2$ design (seed position and with or without plug) with five replicates of 90 seeds.

The micropylar plug was removed at the beginning of each experiment; a dissection needle was used to minimise damage to the embryo and to the endosperm. The seeds in each treatment were germinated between sheets of paper under controlled temperature and light conditions (ISTA, 2005). The germination tests were conducted in a Biotronette ${ }^{\circledR}$ germination machine, at $28-30^{\circ} \mathrm{C}$ with a relative humidity of $50-$ $70 \%$ and a photoperiod of $12 \mathrm{~h} \mathrm{light/dark.} \mathrm{Every} \mathrm{third} \mathrm{day,}$ the seeds were washed with sterile distilled water to prevent infestation by microorganisms. The germinated seeds were recorded daily for 30 days. Germination was expressed as the percentage of the total accumulated germinated seeds.

The number and size of the seeds from each group were compared by analysis of variance (ANOVA). Correlations and linear regressions were used to establish the relationships between the groups. Multifactorial (section, presence of micropyle, storage time) ANOVA was used to analyse the differences between treatments. Means were separated by Tukey's multiple comparison method. In all cases, $95 \%$ probability was considered significant. 


\section{Results}

Effect of seed position on seed morphology and mass. The fruits were divided into three sections (basal, middle and apical), and the number of seeds varied according to the original position $(F=105.93, P=0.0001)$. The largest number corresponds to the middle section $(24.28 \pm 9.90)$, with a range of 17 to 30 seeds, followed by the apical section $(14.34 \pm 6.80)$, with a range of 9 to 19 seeds, and then the basal section $(12.07 \pm 5.58)$, with a range of 8 to 16 seeds. Meanwhile, the weight of the seeds is not related to the position inside of the fruit $(F=0.27, P=0.76)$ (Figure 1A, B).

The size of the seeds was significantly correlated with the group, both in length $(F=231.50, P=0.0001)$ and in its Feret diameter $(F=68.15, P=0.0001)$. Compared with the basal $(2.07 \mathrm{~cm} \pm 0.26 \mathrm{~cm} \pm 1.64$ and 0.16 , respectively) and apical $(2.06 \mathrm{~cm} \pm 0.15 \mathrm{~cm}$ and $1.64 \pm 0.16$, respectively) sections, the seeds from the fruits in the middle section were both longer and wider $(2.67 \mathrm{~cm} \pm 0.26$ and $1.88 \mathrm{~cm} \pm 0.21$, respectively) $(P<0.05$, Figure $1 \mathrm{C}, 1 \mathrm{D})$.

Seed viability. The viability of the seeds in all sections remained essentially constant for 6 months $(P \geq 0.05)$, ranging between 96 and $100 \%$, declining only in the seventh and eighth months $(F=3.00$ and $P=0.07)$ and decreasing by 7 to $20 \%$ in the last month of storage (Figure 2).
Seed position and plug micropyle versus germination and dormancy. The position of the seeds in the fruit did not affect germination rates. There were no significant differences between the three groups during the nine months of the study $(F=1.86, P=0.17)$. In contrast, the germination percentages increased in proportion to storage time $(F=73.09$, $P=0.001)$, although germination was poor during the first four months $(P>0.05)$ and can only be considered significant beginning in the fifth month $(P<0.05)$; statistically, the germination rates remained steady until the sixth month (36.7 \%,P<0.05) and then increased by 1.5 - and 2 -fold in the last two months $(P<0.05)$ (Table 1$)$.

In contrast, in seeds without micropylar plugs, both storage time and the position in the fruit had significant effects on germination $(F=26.85, P=0.0001, F=9.88, P$ $=0.0002$, respectively) (Table 1 ). Micropylar plug removal caused a decrease in germination, to a reduction of nearly $90 \%$ in the last month. This effect was observed in all three groups. However, seeds in the basal group were more robust $(P<0.05)$, given that during the fifth and sixth months, they showed the same germination rate as the undamaged seeds $(P>0.05)$, and in the last two months, the difference was smaller than that found in the middle and apical groups (half and one-fifth of the magnitude, respectively). Regarding the disruption of dormancy, seeds of all groups with micropylar plugs removed showed normal germination until the fifth
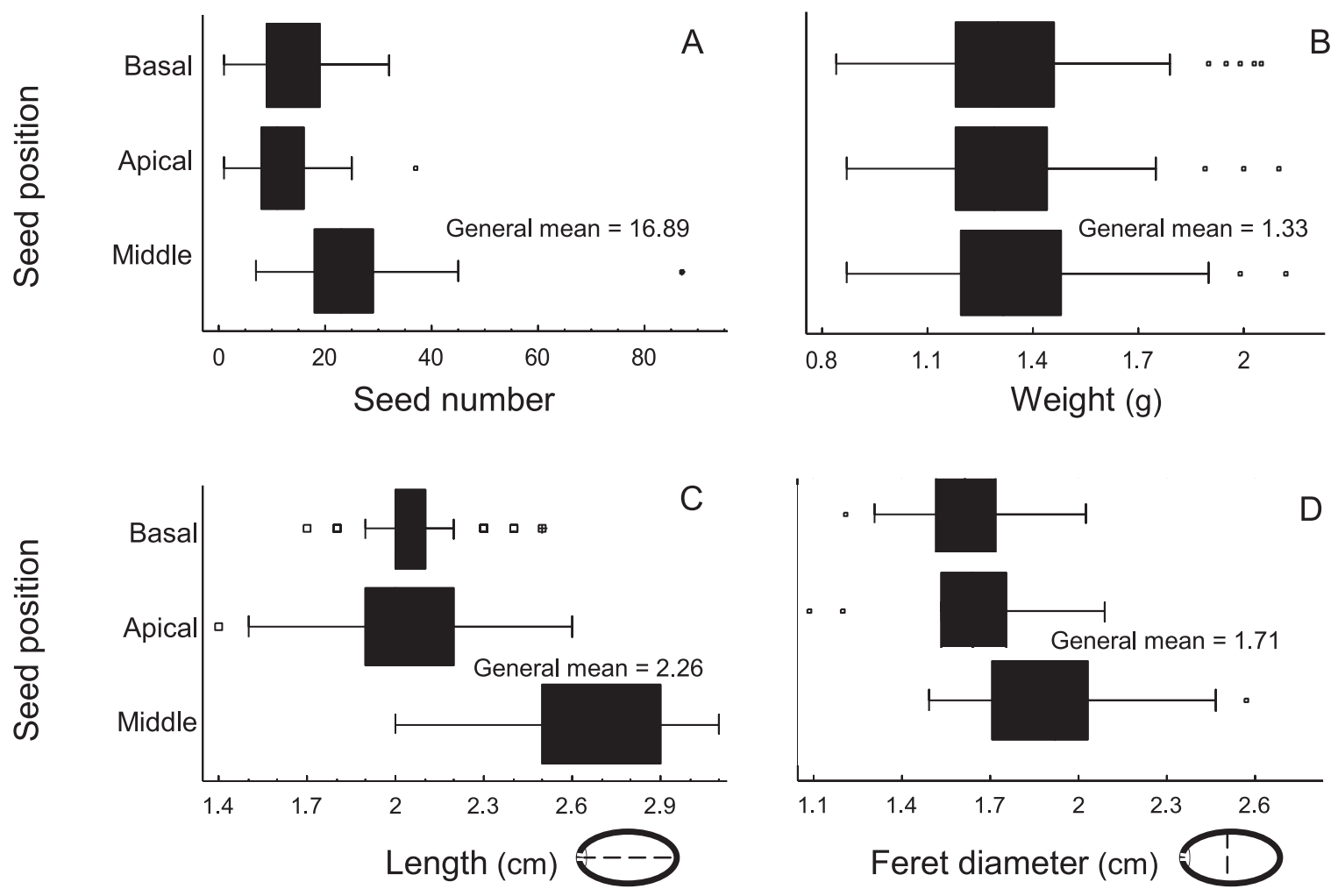

Figure 1. Influence of seed position inside of the fruits of Annona macroprophyllata: number (A), mass (B), length (C), and Feret diameters (D). 


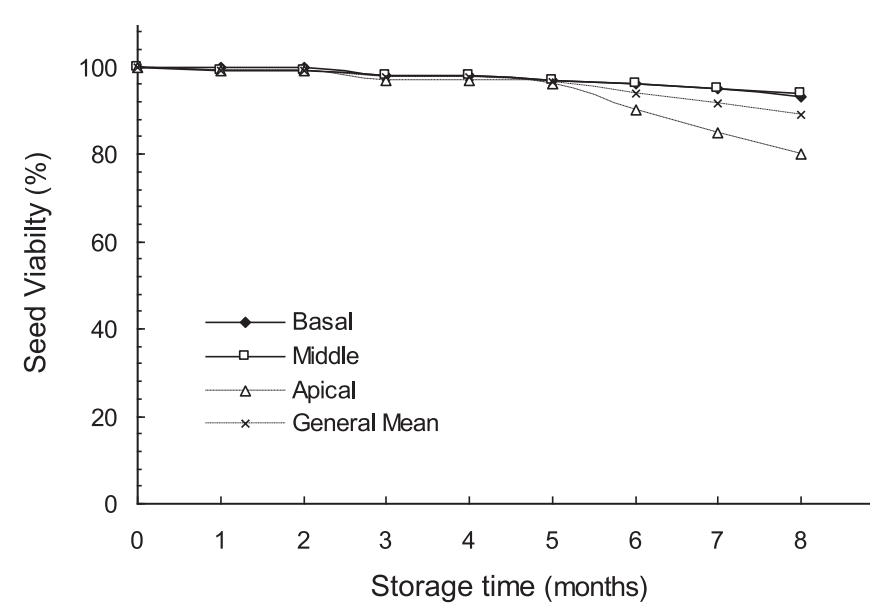

Figure 2. Annona macroprophyllata seed viability during storage.

month $(P<0.05)$ but differed from the intact groups by peaking in the sixth month $(P<0.05)$ rather than later. In fact, in the final months, the germination percentages were the lowest in these groups $(P<0.05)$.

One-way ANOVA indicated that both storage time and the presence of the micropyle plug were significant factors but with opposite effects $(F=90.07, P=0.0001, F=163.52, P=$ 0.0001 , respectively), and multifactorial ANOVA confirmed that there combination was also significant $(F=29.26, P=$ $0.0001)$. The position of the seed was only significant in the basal group, in which the seeds more effectively withstood the removal of the micropylar plug during the months of germination; this group also maintained a comparable germination rate to that recorded for the undamaged seeds in the sixth month $(F=4.08, P=0.24)$.

Other differences between treatments are associated with the onset of germination (Figure 3). Most of the seeds took approximately 15-16 days to germinate. Among the intact seeds, those in the basal group germinated slightly sooner $(F=4.00, P=0.02)$ than those in the other two groups. The removal of the micropylar plug did not appear to influence this parameter $(F=1.76, P=0.12)$, and all groups behaved alike. In these groups, the onset of germination was more common between 13 and 15 days, and higher germination rates generally shift three days after the initial germination (Figure 3). In some cases, germination was found at 11 days. Storage time did not affect the onset of germination $(F=0.76, P=0.47)$; it seems to be a solid pattern, at least in the months with the most germination (months 5-8).

The germination period was similar in the three groups ( $F=2.67, P=0.08)$ and increased with each passing month $(F=154.79, P=0.001)$. Clearly, increasing the number of germinated seeds widens the germination period (Figure $4 \mathrm{~A}$ ); therefore, germination shifted from sporadic (in a single day) in the first months of storage to intervals of 15 days in the last months. The most common germination period was between 9 and 14 days, showing two major peaks in the germination frequency $(P<0.05)$. In the seeds without micropylar plugs, the germination period was also longer in the months when it occurred $(F=59.48, P=0.001)$, but there were also no differences between groups $(F=1.99$, $P=0.15)$ except in the sixth month $(P<0.05)$, where both this parameter and the germination percentage were equal to those of intact seeds (Figure 4B).

\section{Discussion}

Annona macroprophyllata is a species whose seeds are characterised as latent and respond only partially to $\mathrm{AG}_{3}$ (González-Esquinca et al., 1997); nevertheless, it is known that a population of seeds that have already broken dormancy will not all be able to germinate. Dormancy was evaluated as a factor in germination rate. The hypothesis established in this work is that the position of the seed in the fruit and the

Table 1. Effects of storage, seed position and the presence of a micropylar plug in the germination of Annona macroprophyllata. Values are represented as the mean and standard deviation for five replicates. Uppercase letters represent comparisons through the columns (time), and lowercase letters represent comparisons between rows (section and presence of micropylar plug).

\begin{tabular}{|c|c|c|c|c|c|c|}
\hline \multirow{3}{*}{$\begin{array}{l}\text { Storage } \\
\text { time } \\
\text { (months) }\end{array}$} & \multicolumn{6}{|c|}{$\%$ total germination } \\
\hline & \multicolumn{3}{|c|}{ Seeds intacts } & \multicolumn{3}{|c|}{ Seeds without micropylar plug } \\
\hline & Basal & Middle & Apical & Basal & Middle & Apical \\
\hline $\mathbf{0}$ & $0 \pm 0 \mathrm{C}$ & $0 \pm 0 \mathrm{C}$ & $0 \pm 0 \mathrm{C}$ & $0 \pm 0 \mathrm{C}$ & $0 \pm 0 \mathrm{C}$ & $0 \pm 0 \mathrm{C}$ \\
\hline 1 & $0 \pm 0 \mathrm{C}$ & $0 \pm 0 \mathrm{C}$ & $1.1 \pm 1.9 \mathrm{C}$ & $0 \pm 0 \mathrm{C}$ & $0 \pm 0 \mathrm{C}$ & $0 \pm 0 \mathrm{C}$ \\
\hline 2 & $3.3 \pm 0 \mathrm{Ca}$ & $0 \pm 0 \mathrm{Ca}$ & $3.3 \pm 3.3 \mathrm{Ca}$ & $1.1 \pm 1.9 \mathrm{Ca}$ & $2.2 \pm 1.9 \mathrm{Ca}$ & $1.1 \pm 1.9 \mathrm{Ca}$ \\
\hline 3 & $13.3 \pm 3.3 \mathrm{Ca}$ & $6.6 \pm 3.3 \mathrm{Ca}$ & $5.5 \pm 1.9 \mathrm{Ca}$ & $11.1 \pm 3.8 \mathrm{Ca}$ & $4.4 \pm 1.9 \mathrm{Ca}$ & $0 \pm 0 \mathrm{Ca}$ \\
\hline 4 & $14.4 \pm 19.2 \mathrm{Ca}$ & $3.3 \pm 3.3 \mathrm{Ca}$ & $6.6 \pm 5.8 \mathrm{Ca}$ & $5.6 \pm 1.92 \mathrm{Ca}$ & $1.1 \pm 1.92 \mathrm{Ca}$ & $2.2 \pm 1.9 \mathrm{Ca}$ \\
\hline 5 & $45.5 \pm 15.0 \mathrm{Ba}$ & $39.9 \pm 6.7 \mathrm{Ba}$ & $43.3 \pm 0 \mathrm{Ba}$ & $23.3 \pm 15.3 \mathrm{Ba}$ & $8.9 \pm 8.4 \mathrm{Bb}$ & $14.4 \pm 3.9 \mathrm{Bb}$ \\
\hline 6 & $36.7 \pm 20.8 \mathrm{Ba}$ & $33.3 \pm 17.3 \mathrm{Ba}$ & $43.3 \pm 3.3 \mathrm{Ba}$ & $35.2 \pm 4.2 \mathrm{Aa}$ & $17.8 \pm 1.9 \mathrm{Ab}$ & $27.8 \pm 3.9 \mathrm{Ab}$ \\
\hline 7 & $55.5 \pm 8.4 \mathrm{Aa}$ & $53.3 \pm 14.5 \mathrm{Aa}$ & $58.8 \pm 3.8 \mathrm{Aa}$ & $26.7 \pm 12 \mathrm{Bb}$ & $13.3 \pm 12.0 \mathrm{Bb}$ & $22.2 \pm 5.1 \mathrm{Ab}$ \\
\hline 8 & $71.1 \pm 13.5 \mathrm{Aa}$ & $61.1 \pm 11.7 \mathrm{Aa}$ & $63.3 \pm 12 \mathrm{Aa}$ & $14.4 \pm 10.7 \mathrm{Cb}$ & $7.8 \pm 5.1 \mathrm{Bb}$ & $10.0 \pm 6.7 \mathrm{Bb}$ \\
\hline
\end{tabular}




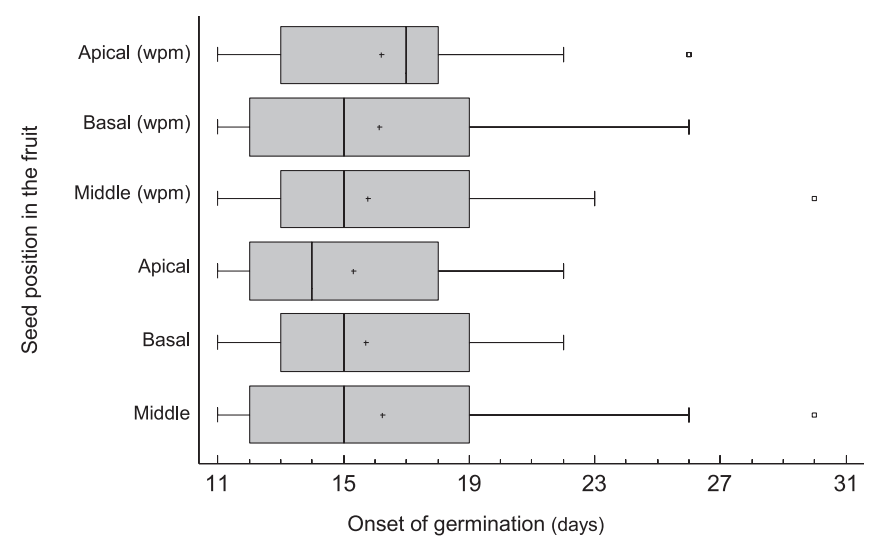

Figure 3. Onset of germination in Annona macroprophyllata seeds. $\mathrm{Wpm}=$ seeds without micropylar plug.

presence of a micropylar plug may affect both germination and dormancy.

The fruits of Annona macroprophyllata present a variable number of seeds, with the ones in the middle region being the largest and most plentiful. The variation in the number of seeds in this species can be related to pollination, in which not all carpels and thus not all ovules are fertilised (Gottsberger, 1999; Gottsberger, 2012), as in the case of $A$. muricata and A. cherimolia. When the ovule is not fertilised, the corresponding carpels tend not to develop, thereby decreasing the number of seeds and, in some cases, even deforming the fruits. It may also be that the greater size of the middle seeds is related to morphogenesis (time of fertilisation), photosynthate supply, and the availability of nutrients and water arriving from the mother plant through the extension of the receptacle, which covers more than half the length of the fruit. González-Esquinca et al. (1997) states that the viability of this species decreases from 100 to $60 \%$ after seven months. In this study, the seeds of all sections maintained viability higher than $80 \%$ for eight months. The loss of viability appears to be associated with the apical section. Although the position of the seeds of A. macroprophyllata fruits did not influence the germination behaviour, as has been indicated by González-Esquinca et al. (1997), germination is scant in the early months and increases (but without reaching $100 \%$ ) as storage time passes. This behaviour may be associated with different levels of dormancy regulated by the balance of phytoregulators (Ferreira et al., 2002; da Silva et al., 2007; de Oliveira et al., 2010; Socolowski and Cicero, 2011). Van Setten and Koek-Noorman (1992) proposed the alternate explanation that Annonaceae seeds contain small, underdeveloped and immature embryos when dispersed, and because of this lack of maturity, they require time for growth after dispersion. However, it has been reported that the embryo of A. macroprophyllata fully develops when the seed is dispersed (González-Esquinca $e t$ al., 1997). In any case, our data indicate that seeds possess survival strategies that allow the anticipation of germination after the first months post-dispersion.

The absence of the micropylar plug induced the same effect in the seeds of the three analysed groups and in the nine storage times tested; nevertheless, they showed clear differences from the undamaged seeds. Most importantly, the percentage of seed germination decreased to $38 \%$ in the seeds without the plug, peaking in the sixth month (March) instead of the usual eight month (May). The absence of the micropylar plug is a signal that enables a small amount of early germination. Additionally, the germination data for the
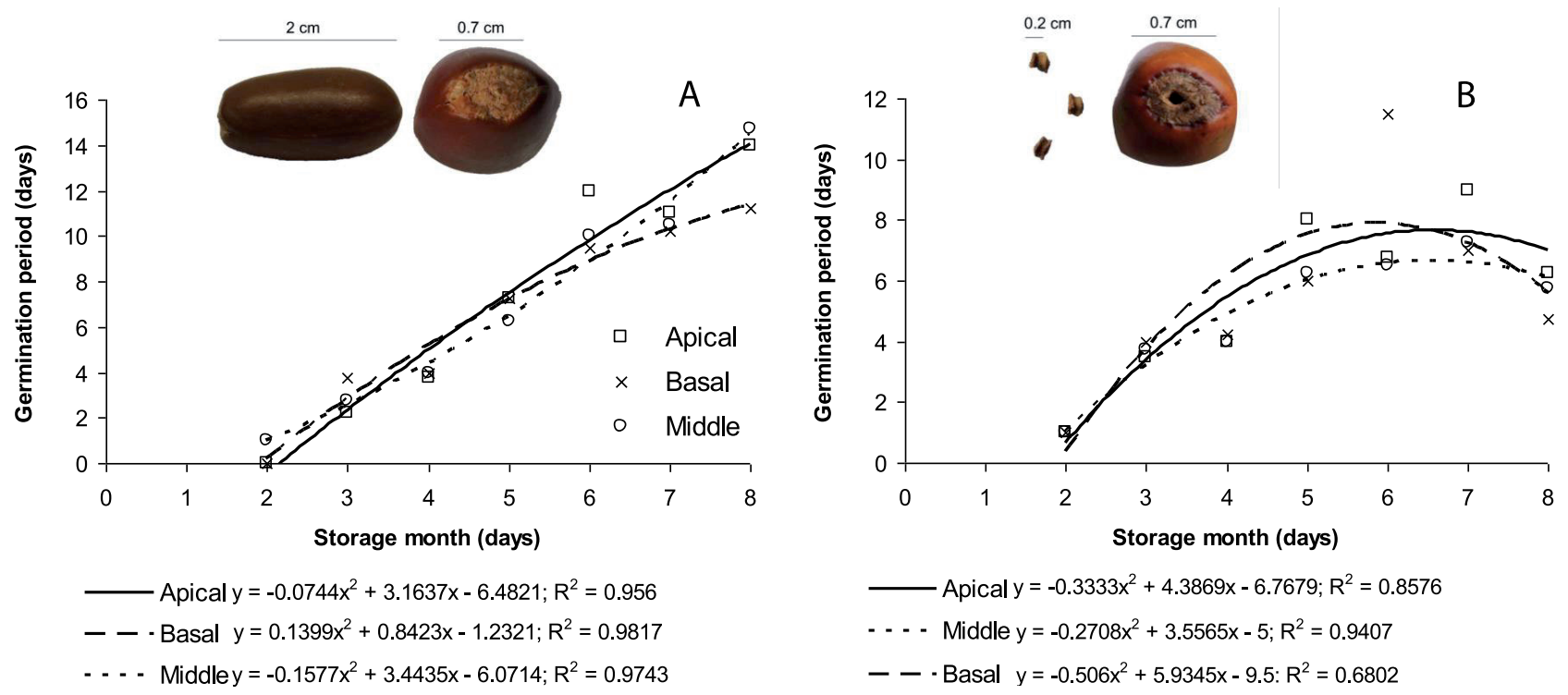

Figure 4. Behaviour during the 8-month germination period of stored Annona macroprophyllata seeds. (A) intact seeds, (B) seeds without micropylar plugs. 
seeds without micropylar plugs show a normal distribution, decreasing after the sixth month. Notably, throughout this treatment, the seeds showed high susceptibility to contamination by microorganisms; this indicates that the absence of the plug prevents the regulation of water intake and facilitates the entry of pathogens that damage the endosperm and embryo before germination begins. The micropylar plug, as a morphological structure, is not the cause of dormancy in seeds of A. macroprophyllata, but it may be involved in controlling the flow of water.

Germination (emergence of the radicle) is evident between 13 and 15 days of imbibition, regardless of any factor analysed in this work, as a consistent pattern that is triggered by the soaking. Thus, the lag period in germination is increased as a function of time; the desynchronisation of germination appears to be due to different depths of dormancy in the seeds.

Annona macroprophyllata is a species that grows in tropical deciduous forests in which the rainy and dry seasons are distinct; therefore, one adaptation for their survival is the timing of germination with the rainy season, which is possible with a dormancy period. Chiang et al. (2011) and Nakayabashi et al. (2012) noted that the degree of maturity of seeds can be induced by climatic factors, and in spontaneous conditions, plants must respond to changing conditions in time and space. If this is true, erratic germination and, consequently, the dormancy of A. macroprophyllata, constitutes a programmed strategy to adapt to small and large changes in the environment (a fact noted by Snyder, 2006; Donohue et al., 2010; Wang et al., 2012), allowing the survival of the species by controlling the propagation mechanisms in response to the close relationship that the species establish with the environment, using intricate ecological processes.

\section{Conclusions}

The position of seeds in the fruit and the presence of a micropylar plug are not important factors for the maintenance of dormancy; however, storage time is critical and in fact synchronises germination with the onset of the rainy season, ensuring environmental conditions conducive to the survival of the species in the seedling stage. It is possible that the maintenance of the "micropylar plug" supports seed viability during the dry months of the months-long dormancy.

\section{Literature cited}

Baskin C.C. and Baskin J.M. 2001. Seeds: Ecology, Biogeography, and Evolution of Dormancy and Germination. Academic Press, San Diego.

Campbell C.W. and Popenoe J. 1968. Effect of gibberellic acid on seed dormancy of Annona diversifolia Saff. Proceedings of the Tropical Region American Society for Horticultural Science 11:33-36.
Chiang G.C.K., Bartsch M., Barua D., Nakabayashi K., Debieu M., Kronholm I., Koornneef M., Soppe W.J.J., Donohue K. and De Meaux J. 2011. DOG1 expression is predicted by the seedmaturation environment and contributes to geographical variation in germination in Arabidopsis thaliana. Molecular Ecology 20:3336-3349.

da Silva E.A.A., de Melo D.L.B., Davide A.C., de Bode N., Abreu G.B., Faria J.M.R. and Hilhorst H.W. 2007. Germination ecophysiology of Annona crassiflora seeds. Annals of botany 99:893-830.

de Oliveira M.C., Ferreira G., Guimarães F.V. and Dias B.G. 2010. Germinação de sementes de atemoia (Annona cherimola Mill. x A. squamosa L.) cv 'Gefner' submetidas a tratamentos com ácido Giberélico (GA3) e ethephon. Revista Brasileira de Fruticultura 32:544-554.

Donohue K., Rubio-de Casas R., Burghardt L., Kovach K. and Willis C.G. 2010. Germination, postgermination adaptation, and species ecological ranges. Annual Review of Ecology, Evolution, and Systematics 41:293-319.

Esashi Y. and Leopold A.C. 1968. Physical forces in dormancy and germination of Xanthium seeds. Plant Physiology 43:871-876.

Ferreira G., Erig P.R. and Moro E. 2002. Uso de ácido giberélico em sementes de fruta-do-conde (Annona squamosa L.) visando à produção de mudas em diferentes embalagens. Revista Brasileira de Fruticultura 24:178-182.

González-Esquinca A.R., Álvarez-Moctezuma J.G. and PorrasPérez. G. M. 1997. Duración de la latencia e importancia de la cubierta dura y de la inmadurez anatómica, en la inhibición de la germinación de la papausa blanca (Annona diversifolia Saff., Magnoliidae, Annonaceae). Investigación, Ciencias y Artes en Chiapas, México 1:37-46.

Gottsberger G. 1999. Pollination and evolution in neotropical Annonaceae. Plant Species Biology 14:143-152.

Gottsberger G. 2012. How diverse are Annonaceae with regard to pollination? Botanical Journal of the Linnean Society 169:245-261.

Graeber K., Voegele A., Büttner-Mainik A., Sperber K., Mummenhoff K. and Leubner-Metzger G. 2013. Spatiotemporal seed development analysis provides insight into primary dormancy induction and evolution of the Lepidium DELAY OF GERMINATION1 genes, Plant Physiology 161:1903-1917.

Hay F.R., Smith R.D., Ellis R.H. and Butler L.H. 2010. Developmental changes in the germinability, desiccation tolerance, hardseededness, and longevity of individual seeds of Trifolium ambiguum. Annals of Botany 105:1035-1052.

ISTA (International Seed Testing Association). 2005. International Rules for Seed Testing Edition 2005. International Seed Testing Association, Bassersdorf.

Marroquín-Andrade L.M., Hernández-Ramos R., Martínez-Solís J. and Vergara-Sánchez M.A. 1997. Tratamientos pregerminativos en semillas de ilama (Annona diversifolia Saff). Revista Chapingo. Serie Horticultura 3:61-64.

Moravcová L., Perglová I., Pyšek P., Jarošík V. and Pergl J. 2005. Effects of fruit position on fruit mass and seed germination in the alien species Heracleum mantegazzianum (Apiaceae) and the implications for its invasion. Acta Oecologica 28:1-10.

Nakabayashi K., Bartsch M., Xiang Y., Miatton E., Pellengahr S., Yano R., Seo M. and Soppe W.J. 2012. The time required for dormancy release in Arabidopsis is determined by DELAY OF GERMINATION1 protein levels in freshly harvested seeds. Plant Cell 24:2826-2838. 
Sharma S., Kaur A. and Sital J.S. 2009. Effect of storage on germinability and composition of seeds from different positions on soybean stem axis. Indian Journal of Agricultural Biochemistry 22:94-97.

Snyder R.E. 2006. Multiple risk reduction mechanisms: can dormancy substitute for dispersal? Ecology Letters 9:1106-1114.

Socolowski F. and Cicero S.M. 2011. Use of growth regulators to overcome seed dormancy in Xylopia aromatica (Annonaceae). Seed Science and Technology 39:21-28.

Svoma E. 1998. Seed morphology and anatomy in some Annonaceae. Plant Systematics and Evolution 209:177-204.

van der Heijden E. and Bouman F. 1988. Studies in Annonaceae. $\mathrm{X}$. Seed anatomy of the Annona group. Botanische Jahrbücher für Systematik, Pflanzengeschichte und Pflanzengeographie 110:117-135.

van Setten A.K. and Koek-Noorman J. 1992. Fruits and seeds of Annonaceae: Morphology and its significance for classification and identification. Bibliotheca Botanica 142:1-101.

Wang A.B, Tan D.Y., Baskin C.C. and Baskin J.M. 2010. Effect of seed position in spikelet on life history of Eremopyrum distans (Poaceae) from the cold desert of north-west China. Annals of Botany 106:95-105.

Wang L., Baskin J.M., Baskin C.C., Cornelissen J.H.C., Dong M. and Huang Z. 2012. Seed dimorphism, nutrients and salinity differentially affect seed traits of the desert halophyte Suaeda aralocaspica via multiple maternal effects. BMC Plant Biology 12:170.

Received: June 6th, 2014

Accepted: July 14th, 2014 